DOI: doi.org/10.21009/IJLECR.051.07

Received: 20 January 2019

Revised: 1 February 2019

Accepted: 12 March 2019

Published: 30 June 2019

\title{
POWER DISCOURSE OF SEXUALITY IN SHORT STORIES TITLED MATA TELANJANG (2014) BY DJENAR MAESA AYU AND USHA MY THIRD CHILD (2007) BY SUCHEN CHRISTINE LIM
}

\author{
Nailul Ulah Al-Chumairah ${ }^{1, a)}$ \\ Magister Kajian Sastra dan Budaya, Fakultas Ilmu Budaya, Universitas Airlangga. ${ }^{1)}$ \\ naymachfud@gmail.com ${ }^{\text {a) }}$
}

\begin{abstract}
The concept of Michel Foucault power of sexuality perspective has strategic unities. This research uses the genealogy approach of power perspective by Michel Foucault. In this case to dissect relations and effects that arise from the relation of each discourse of sexuality power in the short stories of Mata Telanjang written by Djenar Maesa Ayu and Usha My Third Child written by Suchen Christine Lim. Based on the research that will be conducted, the researcher found 1) Relation of Power Discourse of Sexuality with Economic Practice, Household (Marriage), and Environmental System. 2) The Relationship of Power Discourse of Sexuality with Body Hysterization Through Medical Practice, and 3) The Relationship of Sexuality Powers Towards Teenage Girl.
\end{abstract}

Keywords: Critical Discourse Analysis (CDA), genealogy, power, literature, sexuality

The issue of sexuality is a problem that never stops in the circle of discourse because sex is part of human existence. The issue of sex is not only a matter of daily conversation or non-academic knowledge but has been turned into an academic study. As an issue that is always discussed, whether academic or non-academic, sex becomes a part of a discourse. This discourse is reflected in various society's values and norms related to sex and the construction of sexual characters that are socially attached to men and women, which is the form of a non-academic sex discourse. With this perspective, the study of sex or sexuality is seen as something that is constructed, not neutral or independent. There are certain powers which lie behind the discourse which operate their power through various mechanisms of control, discipline, and normalization in the form of values and practices of sexuality.

This power relation runs systematically so as to create latent hegemony, where one party is not aware of the hegemony of the other party, and even accepts its subordinate position as a truth. The discussion of power relations in the discourse of sexuality cannot be separated from the discussion of gender since stereotypes embedded in men and women in general do not necessarily rely on biological characteristics but on social construction.

In this study, there are limits that the author provides for a more focused problem-solving space. The study of female sexuality which is being discussed on this study relies on the interpretation of sexuality as a concept that houses the social construction of female sex. For 
example, the sexual nature and character of women that are built up in community spaces have an influence on the formation of women's sexual attitudes, behaviors and experiences. Since the narratives of sexuality are built on the role of community groups, the writer views sexuality as a discourse. Foucault (2008) revealed that by using power and knowledge relations, it can be seen how power operates behind a discourse. This power then has the authority to build constructions about sexuality, which in this case is female sexuality.

According to Foucault (2002: 120-126), the discourse of power can be spread through relations in various fields. Power is everywhere and arises from the relations between the various dominant forces that occur absolutely and are not dependent on human consciousness. Foucault also does not place power as a possession in the hands of the State or the monolithic authority, he sees power as a relationship, not just a coercive one-way, especially from top to bottom. Power is also a strategy in which there are systems, rules, arrangements and regulations. Power does not come from the outside. Power determines the structure, rules, and relationships from within and allows everything to happen (Foucault, 2000: 144).

The object chosen by the author is an anthology of short stories titled Anthology of Short Stories from Indonesia - Malaysia - Singapore. The author deliberately chose only two works in the anthology as the focus of the research object, namely Mata Telanjang by Djenar Maesa Ayu (Indonesia) and Usha My Third Child by Suchen Christine Lim (Singapore). This is because both works are still written in the original language (Indonesian and English), not through the process of translation. Considering the object is a literary work, the writer is very careful and prefers works that are still in the original language rather than translation because it is feared that there are differences in meaning in the translation process.

What's interesting in these two different short stories is the discourse of female sexuality produced by the author. The writer believes that the short stories in this anthology are carefully selected and are considered capable of being cultural representations or local aspirations of the country concerned. Clearly, there are differences in cultural colors that are visible from the two short stories selected. Mata Telanjang talks a lot about labeling women's bodies which are considered as objects while Usha My Third Child discusses different female sexuality which is about disciplining the female body through state policy.

\section{METHOD}

This type of research is a qualitative descriptive study. Citing what was said by Jorgensen and Philips (2007: 116), there are several theories and methods found in the analysis of critical discourse. These theories and methods can be used as a basis for empirical studies which examine the relationship between discourse and socio-cultural development in various social domains. In this regard, this study uses power genealogy approach of Michel Foucault's perspective.

Scheurich and McKenzie (2012: 219) explain that Foucault, in his methodology of archeology and genealogy studies, can be interpreted broadly as a qualitative method because it always uses text as data. The genealogical approach in this research acts as a scalpel to analyze the relationships and effects that emerge from the relations of each discourse on the power discourse of sexuality. It also aims to develop a deep understanding of a series of complex concepts that are intertwined with discursive structures and discursive relationships which exist in Mata Telanjang and Usha My Third Child.

Data sources from this study are short stories titled Mata Telanjang and Usha My Third Child in the Anthology of Short Stories from Indonesia - Malaysia - Singapore, which is the results of the collaboration from the Malaysian Translation \& Book Institute, the Indonesian Torch Library Foundation, and the National Arts Council Singapore. Regional differences attract the writer to see how certain discourses are echoed and being (re)produced. 
The data in this study are in the form of segments or fragments of story texts in the short stories of Mata Telanjang and Usha My Third Child relating to the discourse of the power of sexuality which are relevant in accordance with the discursive structure of power and discursive relations of power. In accordance with the object of research in the form of literature, data collection techniques used in this study are document techniques consisting of literature research techniques and note taking techniques. In data analysis, this study used interpretive descriptive analysis techniques. To answer the focus of research, it is necessary to interpret the data according to the concerns namely discursive structure and discursive relations.

\section{The construction of discourse on female sexuality}

\section{RESULTS AND DISCUSSION}

If human body is indeed natural and deterministic, then the experience of it will be constant and universal. However, it is believed by many that gender differences affect the image of the body (sexuality). The question is, if sexuality is a social artifact, then what power dominates the social construction of sexuality? When it is examined further, the mainstream tendency for the study of sexuality is based on the phallocentric paradigm. Phallocentric comes from the word phallus which means penis, and centric which means center. Phallocentric means centered on the penis: male or masculine. This paradigm not only underlies the study of sexuality, but also the building of social science in general. For this reason, on the next paragraph the author will discuss the construction of sexuality that has been raised by several social researchers.

Foucault defines sexuality as a discourse about sex or sexual intercourse between individuals (2008). The issue of sex or sexual relations has historically been discussed as a repression of power manifested in two contradictory forms at once. On the one hand, the problem of sex is displayed in the form of control, in the form of taboo or prohibition against talking about sex and sexual activities. However, on the other hand, repression of sexuality is also manifested in the liberation of vulgar sex talk, and the establishment of rules that legitimize sexual vulgarity or taboo.

Emile Durkheim, in her concept of division of labor states the progress of society and civilization is determined by the progress of the division of tasks based on sex (Durkheim, 1960). In the division of tasks, women are naturally based on their reproductive capacity and sensory impulses. They are more appropriate to play aesthetic roles and functions, while men with perfectly developed intellectual capacities play a role in the instrumental functions. Durkheim deliberately justifies a form of subordination of men to women, with the legitimacy that the differences in sex as well as the different roles between men and women are "natural" (given). In this context, differences in sex are not only psychological and physiological organic but also social, in the sense that these differences are functional to society. This differentiation will guarantee the creation of harmony and social stability. Thus, in the name of social stability and harmony, subordination to women is legitimated.

In line with Emile Durkheim, Max Weber also gives his assumptions about the relations and the nature of women and men which indicates the same stereotype as Durkheim. This is clearly seen in the concept of male and female relations in his analysis of patriarchy. According to him, patriarchy describes an organization of social power between men as leaders over women, children and slaves (Weber, 1968). Here, men have the privilege compared to women to look for sources of power. In his description, using an ideal type of analysis tool of the facts he studied especially about patriarchy, Weber illustrates that patriarchal power is personal prerogative; men are able to exercise their power without obstacles, at least by "tradition or competing forces". In their ideal type, male domination is absolute and legitimated and at the same time limited by traditional norms.

The critical expression of Foucault, Weber and Durkheim about sexuality, patriarchy, and the division of labor shows that the domination of men over women is a natural phenomenon that is 
natural-based on differences in their capacities. This kind of thought makes subordinating women a legitimate thing. This further strengthens social construction that places women in subordinate positions, and is valid to be controlled and subdued.

\section{The Relationship of the Power of Sexuality with Economic and Domestic Practices}

Social construction and social science theories that are paradigmatic for men (phallocentric) affect studies in other areas including the issue of sexuality. This of course affects social practice by making men the center or subject of life. As for women, they are only a complement to life, whose existence depends on the existence of men. This is the writer found in the short story titled Mata Telanjang, when the character Nay who is an entertainer in a nightclub is dancing naked in front of her male customers. The reality of Nay's life is not defined as having an agency, but rather subjecting to men's glasses and perspectives. In this context, women are only positioned as objects, as in the quote Nay said, '...Dan dalam kegelapan, aku hapal mata-mata itu. Mata penuh nafsu. Mata yang merasa berkuasa karena punya banyak uang!' [... And in the dark, I am familiar with those eyes. Lustful eyes. Eyes that feel powerful because they have lots of money!] (Ayu 2014).

In the short story, the writer finds that the power of sexuality runs through economic and household practices. This is a very complex arena in the relations of power, knowledge, and enjoyment in the form of sexuality. Sexuality is regulated and directed to form an obedient individual. Such is the case with the power of sexuality in economic practice with commercial aims which is reflected in the quotation below.

'Aku melirik beberapa kawanku yang sudah bersandar di sofa setengah mabuk. Semuanya bengong disesah birahi menatap liuk tubuhnya yang sudah setengah telanjang. Aku sengaja duduk agak menjauh, menghindari tatapan matanya. Ia menaikkan satu kakinya di atas meja. Semua menahan napas dan menelan ludah, ketika ia melepas lilitan kain terakhir di tubuhnya. Saat itulah kami bertatapan. Rasanya aku tak akan pernah mungkin melupakan tatapan mata itu. Bukan tatapan mata yang menghiba atau penuh kesedihan. Tapi tatapan yang meledek sinis. Apa yang diledeknya? Nasibnya, atau kami para lelaki yang memandangnya penuh birahi?

Ah, bagaimana bisa mata seorang penari telanjang membuatku begini berdebar?'

[I glanced at some of my friends who were already leaning on the couch half drunk. Everyone stunned lustfully staring at the contortion of her body that was half-naked. I deliberately sat a little away, avoiding her eyes. She raised one foot on the table. Everyone held their breath and swallowed hard, when she took off the last cloth in his body. That's when we stared at each other. I don't think I will ever forget those eyes. Not a look of grieving or sad eyes. But the look that was teasing cynically. What did she tease? Her fate, or we the men who looked at her passionately?

Ah, how can the eyes of a stripper make me flutter like this?] (Ayu, 2014)

Nay is the object men who are more concerned with the physical appearance of the women they had order or how their bodies are captured by the five senses. The identity of the women of that night has shifted from like the name or where the women came from to be merely their body. This was also said by the main male figure, "Nay? Pasti bukan nama asli" [Nay? Definitely not a real name] (Ayu, 2014). The man thought so because it was true that usually the women in the nightclub always used pseudonyms, whose customers did not even know their real names since whether the name is real or not was not important to mark a woman's identity.

Although this short story still gives Nay's character the opportunity to speak, each part of it reinforces the author's hypothesis that she lacks the autonomy and ability to make choices. Nay was described as having the awareness that she did not want to go through her work by saying 'tak rela sebenarnya tubuh ini digelar' ['I do not desire for this body to be consumed] (Ayu, 2014), but she 
was forced by her drunk husband to become a family support. Again, Nay was forced to submit without being able to offer resistance. In the arena of marriage, Nay became an object that was easily arranged by her husband. This economic issue can also be used as a power control, as quoted below,

'Aku perlahan naik ke panggung dengan gerak kaki tenang, tapi mengundang. Daya pikat seorang penari telanjang dimulai dari kemunculannya. Begitu aku mampu membuat puluhan pasang mata itu terpesona pada liukanku, selanjutnya tinggal memainkan rasa penasaran mereka. Menggoda imajinasi mereka. Saat itulah mereka menjadi sekawanan serigala dengan mata tak sabar ingin menyerang. Setiap liukan menjadi pemandangan yang tak akan pernah dibiarkan lewat begitu saja oleh mata jalang.'

[I slowly went up to the stage with calm, but inviting. The allure of a stripper starts from their appearance. Once I was able to make dozens of eyes fascinated by my contortion, then I just played their curiosity. Tempting their imagination. That's when they became a pack of wolves with eyes eager to attack. Every corner of the body becomes a scene that will never be let go by the predacious eyes.] (Ayu, 2014)

The power discourse of sexuality in the quote above suggests as a sign that economic problems can be used as a control of power. In Mata Telanjang, every woman in the nightclub has their own tricks and styles to keep themselves liked until they are able to retain customers. They use it as a control over their sexuality which is based on knowledge. Knowledge that underlies the existence of power, and also power will underlie knowledge. So that power and knowledge will not be separated from each other and will continue to need each other.

\section{The Relationship of Power Discourse of Sexuality and Body Hysterization through Medical Practices}

Meanwhile, Usha My Third Child has a discourse on the power of sexuality regarding hysterization of the body through medical practice. This is demonstrated by a power strategy that runs when body is analyzed and integrated into the area of medical practice which will eventually be placed in organic communication with the social body. Thus, body can be constituted as the central identity.

'...The nurse at the ward gave me some forms to sign. Under the heading "Reasons for Termination of Pregnancy" I scribbled "Obeying government orders to stop at two". The nurse smiled. For a brief moment, looking across the counter at each other, we were fellow conspirators who understood each other. Women tired of being told what to do how many children to have and the penalties. Ah, the penalties! You would lose your place in the queue for public housing. If you had a third child, you were moved to the end of the housing queue and had to start all over again. And I had wanted them to move into a five-room flat as soon as possible. For the sake of peace. For the sake of my mother and two brothers living with us. Another penalty was that your third child was not allowed to go to school of your choice even if his or her siblings were already in that school. A slew of such policies had hit us in the 1970s when Dave was unemployed.' (Lim, 2007:126)

In the 1970s, Singapore did indeed have a nuclear family planning campaign, even though it was finally revoked. The program was intended to slow down population growth, as also in the above quote. However, the birthrate that plummeted in the 1980s made various government targets fail. Finally, Singapore launched a new campaign, urging its citizens to have three or more children 
with the slogan: "Have Three or More Children if You Can" (Armandhanu, 2015).

Before the policy was revoked, there were separate sanctions for couples who had more than two children, with the taking of several rights of its citizens such as getting the opportunity to go to school or housing facilities. At that time, Singapore was aggressively distributing contraceptives and launched the modern family planning movement. It can be seen that the person most affected by this rule is women. Their body are regulated by the state institutions and disciplined by imposing sanctions that force women to abort children.

\section{The Relationship of the Power Discourse of Sexuality towards Adolescent Girls}

Meanwhile, sexuality power relations in 17-year-old girls can also be found in the short story Usha My Third Child. Usha is a 17-year-old teenager, who stutters when she feels nervous, enthusiastic, or angry. Usha is also the second child of three siblings, all of whom are women. Usha was born in Singapore into an ethnic Indian family, which greatly put men on top of everything. Since Usha usually stutters, she often becomes the target of her parents' angry rants. She was being looked down by her own family, especially when she was pregnant out of wedlock with her Chinese boyfriend. Usha's family were furious and her boyfriend's parents also didn't allow them to get married because of ethnic differences.

For Indians, it is very important to get married with fellow Indians to protect their lineage. This makes his parents feel ashamed because Usha is in a relationship with a Chinese man. However, when his parents found out that Usha was pregnant with a boy, his family immediately changed their minds. The father uses his power as the leader of the household to take Usha's baby and forced to acknowledge the baby as his child.

"My... my... my father wants to put his name down as... as the father. He... he's mad. It's my... my... my baby. My baby. I... I want to keep him. Do... do what's best for him. If... if giving him to other pe- pe- people is best, then I... I... I give him up.” (Lim, 2007:125)

Usha's family looked down on her, ignored the issue of Usha getting pregnant out of wedlock, but was very concerned about the fact that the child Usha was carrying was a boy. This means that women are depicted as entities whose existence is not as important as men, describing an organization of social power between men as leaders over women, children and slaves. Here, men have the privilege compared to women when it comes to sources of power.

\section{CONCLUSION}

The relationship of power discourse in sexuality with economic and household practices is found in Mata Telanjang. Meanwhile, the relation of power discourse in sexuality regarding hysterization of the body through medical practice and young women is found in Usha My Third Child. Usha My Third Child shows a power strategy that runs when female body is being disciplined and is integrated into the area of medical practice that will eventually be placed in an organic communication with the social body. Thus, the body can be constituted as the central identity. In this context, the definition of sexuality is expanded, not just sex but also includes experiences related to other sexuality (pregnancy, family planning). The discourse of sexuality arises from how a country regulates, maintains and controls the population to remain healthy, productive and stable, and that men are considered more valuable than women.

In Mata Telanjang, the difference in sex is not only psychological and physiological organic, but also social, in the sense that these differences are functional towards society. Thus, in the name of social stability and harmony, subordination to women is something that can be justified, making men the center or subject of life. As for women, they are only a complement to life, whose existence depends on the existence of men. 


\section{REFERENCES}

Armandhanu, D. (2015, Oktober 30). Empat Negara Ini Dorong Warganya Perbanyak Anak. Retrieved Desember 17, 2017, from https://www.cnnindonesia.com/internasional/20151030110856-113-88385/empat-negaraini-dorong-warganya-perbanyak-anak

Durkheim, E. (1960). The Division of Labor In Society. (G. Simpson, Trans.) Illinois: The Free Press of Glencoe.

Foucault, M. (2000). Seks dan Kekuasaan. (S. Rahayu, Trans.) Jakarta: Gramedia.

Foucault, M. (2002). Power / Knowledge. Yogyakarta: Bentang.

Foucault, M. (2008). Ingin Tahu Sejarah Seksualitas. (F. Jakarta-Paris, Trans.) Jakarta: Yayasan Obor Indonesia.

Lim, S. (2014). Usha My Third Child. In T. H. Roosseno, M. S. Rahamad, \& G. L. Sui, Anthology of Short Stories from Indonesia - Malaysia - Singapore (pp. 119-127). Jakarta: Yayasan Pustaka Obor Indonesia.

Noor, A. (2013, Maret 29). Mata Telanjang - Djenar Maesa Ayu. Retrieved from Wordpress: https://agusnoorfiles.wordpress.com/2013/03/29/mata-telanjang/

Weber, M. (1968). Economy and Society. Berkeley/Los Angeles: University of California Press. 